\title{
Blood Pressure Management in Acute Stroke: A Long-Standing Debate
}

\author{
Konstantinos Spengos $^{\mathrm{a}}$ Georgios Tsivgoulis $^{\mathrm{a}}$ Nikolaos Zakopoulos $^{\mathrm{b}}$ \\ ${ }^{a}$ Department of Neurology, University of Athens School of Medicine, Eginition Hospital, and \\ ${ }^{b}$ Department of Clinical Therapeutics, University of Athens School of Medicine, Alexandra Hospital, Athens, Greece
}

\section{Key Words}

Acute stroke $\cdot$ Blood pressure $\cdot$ Hypertension

\begin{abstract}
Although elevated blood pressure (BP) levels are a common complication of acute stroke, whether of ischaemic or haemorrhagic type, a long-standing debate exists regarding the management of post-stroke hypertension. In the absence of solid, randomised data from controlled trials, the current observational evidence allows different approaches, since theoretical arguments exist for both lowering BP in the setting of acute stroke (reduce the risk of stroke recurrence, of subsequent oedema formation, of rebleeding and haematoma expansion in patients with cerebral bleeding) as well as leaving raised BP levels untreated (avoid reduction in cerebral perfusion pressure and blood flow to viable ischaemic tissue in the absence of normal autoregulation). The present review will summarize the evidence for and against the therapeutic manipulation of BP in acute stroke provided by the currently available observational studies and randomised trials, consider the ongoing clinical trials in this area and address the present recommendations regarding this conflicting issue.

Copyright $\odot 2006$ S. Karger AG, Basel
\end{abstract}

\section{Introduction}

Elevated blood pressure (BP) as defined by the World Health Organization and the International Society of Hypertension (systolic BP $>140 \mathrm{~mm} \mathrm{Hg}$ and/or diastolic BP $>90 \mathrm{~mm} \mathrm{Hg}$ ) is established as the most prevalent modifiable risk factor for stroke. Large-scale observational studies have demonstrated that BP values are positively and continuously associated with the risk of stroke in a loglinear fashion [1]. Significant advances in primary and secondary stroke prevention using various antihypertensive agents have been achieved recently. There is now clear evidence that BP reduction protects against first-ever, as well as recurrent stroke independent of baseline BP levels [2-4]. More specifically, systemic reviews of 17 primary prevention trials involving a total of 47,000 participants showed that lowering systolic BP (SBP) by $10-12 \mathrm{~mm} \mathrm{Hg}$ and diastolic BP (DBP) by $5-6 \mathrm{~mm}$ Hg leads to a $38 \%$ reduction in the risk of stroke [2]. Furthermore, a recent meta-analysis of 7 secondary prevention trials involving 15,527 participants demonstrated that the use of BP-lowering agents reduced the risk of recurrent stroke by $24 \%$ [4].

Elevated BP values $(>140 / 90 \mathrm{~mm} \mathrm{Hg})$ are present in up to $80 \%$ of patients with acute stroke $[5,6]$, while almost every fourth patient presents with markedly raised SBP values $>180 \mathrm{~mm} \mathrm{Hg}$. There is no single explanation for the

Konstantinos Spengos, MD

Department of Neurology, University of Athens School of Medicine

Eginition Hospital, Vas. Sofias 82

GR-11528 Athens (Greece)

Tel. +30 6946466 216, Fax +30 210674 2604, E-Mail spengos@hol.gr 
elevation of BP in acute stroke. The main contributing factors include pre-existing hypertension [7], activation of neuro-endocrine systems $[8,9]$, the stress of hospitalisation [10], infarct topography [11], stroke subtype [7, 12, 13 ], stroke severity [14] and the reactive increases in systemic BP in response to raised intracranial pressure [15].

Despite its high prevalence, the optimal management of arterial hypertension during the acute stroke stage has not been established and remains an issue of long-lasting debate and little consensus $[15,16]$. Notably, the results of numerous observational studies, which investigated the relationship of admission BP levels with stroke outcome in patients with ischaemic stroke (IS; table 1) and intracerebral haemorrhage ( $\mathrm{ICH}$; table 2 ) are conflicting and data from randomised controlled studies are still missing [17, 18]. Aim of this review was not to answer this still open question, but to present a critical overview of all arguments pro and contra lowering $\mathrm{BP}$ in the acute setting of stroke on the basis of current observational and randomised evidence, consider the ongoing clinical trials in this area and address the present recommendations regarding this conflicting issue.

\section{Search Criteria}

\section{Observational Studies}

Systemic searches of PUBMED electronic database for published observational studies that reported baseline BP and early ( $<3$ months) outcome (death, dependency, death or dependency, recurrent stroke, early neurological deterioration) were made by K.S. and G.T. The search strategy included the following key words: blood pressure, hypertension, acute, stroke, outcome, prognosis, death, mortality, intracerebral haemorrhage. Additional studies were also sought from references of identified studies and reviews [15-20]. Functional status in the identified studies was typically assessed by the modified Rankin Scale (mRS) and the Barthel Index (BI). Early neurological deterioration in the identified studies was invariable measured with the National Institutes of Health Stroke Scale (NIHSS), the Canadian Stroke Scale (CSS) and the Canadian Neurological Score (CNS). Published reports that presented insufficient data, used other outcome measures or were duplicate articles were excluded. Decisions on inclusion and exclusion of the observational studies were made by consensus of the three authors

\section{Intervention Trials}

Intervention trials (pilot preliminary trials, safety and feasibility studies and randomised controlled trials) that assessed the effect of BP-lowering medications during the first 2 weeks after stroke onset on early ( $<3$ months) outcome were identified through systematic searches of PUBMED and Cochrane electronic databases by K.S. and G.T. The search strategy included the following key words: blood pressure, hypertension, acute, stroke, intracerebral haemorrhage, blood pressure lowering, blood pressure reduction, blood pressure elevation, induced hypertension, pilot trial, safety study, randomised controlled trial. Additional studies were also sought from references of identified studies and reviews [15-20]. Studies that evaluated the impact of BP reduction after the second week of ictus on secondary prevention of stroke and other vascular events were excluded. Published reports that were duplicate articles were not included in the present review. Decisions on inclusion and exclusion of the interventional trials were made by consensus of the three authors.

Table 1. Observational studies investigating the relationship between initial blood pressure (BP) values and short-term outcome ( $\leq 3$ months) in patients with acute ischaemic stroke (IS)

\begin{tabular}{|c|c|c|c|c|c|}
\hline Study & Year & $\mathrm{n}$ & BP timing & BP method & Results \\
\hline Sacco et al. [36] & 1989 & 1,273 & admission (<7 days) & not given & $\begin{array}{l}\mathrm{DBP} \geq 100 \mathrm{~mm} \mathrm{Hg} \text { associated with increased 1-month stroke } \\
\text { recurrence }\end{array}$ \\
\hline $\begin{array}{l}\text { Davalos et al. } \\
{[74]}\end{array}$ & 1990 & 98 & $\operatorname{admission}(<8 \mathrm{~h})$ & not given & $\begin{array}{l}\text { increased SBP associated with early (within first } 48 \mathrm{~h} \text { ) neurological } \\
\text { deterioration (CNS, linear relationship)* }\end{array}$ \\
\hline $\begin{array}{l}\text { Carlberg et al. } \\
{[75]}\end{array}$ & 1993 & 831 & admission (<1 week) & manual & $\begin{array}{l}\text { (a) patients with impaired consciousness: Increased MAP was } \\
\text { associated with 1-month M (linear relationship)* } \\
\text { (b) alert patients: no association between BP and outcome }\end{array}$ \\
\hline Toni et al. [76] & 1995 & 152 & $\operatorname{admission}(<5 \mathrm{~h})$ & not given & $\begin{array}{l}\text { (a) no association between } \mathrm{BP} \text { and progressing neurological deficit } \\
\text { (b) no association between } \mathrm{BP} \text { and } 1 \text {-month M/D }\end{array}$ \\
\hline $\begin{array}{l}\text { Finocchi et al. } \\
\text { [77] }\end{array}$ & 1996 & 351 & $\operatorname{admission}(<48 \mathrm{~h})$ & manual & no association between $\mathrm{BP}$ and 1-month M/D \\
\hline
\end{tabular}


Table 1 (continued)

\begin{tabular}{|c|c|c|c|c|c|}
\hline Study & Year & $\mathrm{n}$ & BP timing & BP method & Results \\
\hline $\begin{array}{l}\text { Chamorro } \\
\text { et al. [78] }\end{array}$ & 1998 & 481 & $\begin{array}{l}\text { repeated recordings } \\
\text { over } 7 \text { days following } \\
\text { admission }\end{array}$ & manual & $\begin{array}{l}\text { moderate }(20-30 \%) \text { drop in MAP on day } 2 \text { after stroke onset was } \\
\text { associated with complete functional recovery (mRS) at } 1 \text { week }\end{array}$ \\
\hline $\begin{array}{l}\text { Dawson et al. } \\
{[68]}\end{array}$ & 2000 & 92 & $<72 \mathrm{~h}$ from ictus & $\begin{array}{l}\text { manual and } \\
\text { beat-to-beat } \\
\text { recordings }\end{array}$ & $\begin{array}{l}\text { increased beat-to-beat MAP and MAP variability was associated } \\
\text { with } 1 \text {-month M/D (linear relationship)* }\end{array}$ \\
\hline $\begin{array}{l}\text { Ahmed et al. } \\
{[79]}\end{array}$ & 2001 & $92^{\star *}$ & $\begin{array}{l}\text { Time of randomisation } \\
(<24 \mathrm{~h})\end{array}$ & not given & $\begin{array}{l}\text { increased BP categorised at different BP levels was associated with } \\
21 \text {-day M/D }\end{array}$ \\
\hline $\begin{array}{l}\text { Bhalla et al. } \\
\text { [80] }\end{array}$ & 2001 & 70 & $<24 \mathrm{~h}$ & $\begin{array}{l}\text { manual and } \\
\text { ABPM }\end{array}$ & $\begin{array}{l}\text { (a) no association between casual and } 24 \text {-hour SBP/DBP and } \\
\text { functional status at } 1 \text { week } \\
\text { (b) increased day to night time BP change was associated with } \\
\text { complete functional recovery (mRS) at } 1 \text { week }\end{array}$ \\
\hline $\begin{array}{l}\text { Boreas et al. } \\
{[81]}\end{array}$ & 2002 & 403 & $\begin{array}{l}\text { repeated recordings over } \\
4 \text { days following admission } \\
(24 \mathrm{~h})\end{array}$ & manual & $\begin{array}{l}\text { (a) no association between admission SBP/DBP and outcome } \\
\text { (b) night-time } \mathrm{SBP} \geq 165 \mathrm{~mm} \mathrm{Hg} \text { and night-time DBP } \\
\leq 60 \mathrm{~mm} \mathrm{Hg} \text { were associated with } 3 \text {-month } \mathrm{M} / \mathrm{D} \\
\text { (c) decrease in daytime } \mathrm{DBP} \text { (between day } 0 \text { and day } 4 \text { ) } \geq 10 \mathrm{~mm} \mathrm{Hg} \\
\text { was associated with } 3 \text {-month } \mathrm{M} / \mathrm{D}\end{array}$ \\
\hline $\begin{array}{l}\text { Leonardi-Bee } \\
\text { et al. [31] }\end{array}$ & 2002 & 17,398 & $\operatorname{admission}(<48 \mathrm{~h})$ & not given & $\begin{array}{l}\text { (a) } 14 \text {-day } \mathrm{M} \text { increased for every } 10 \mathrm{~mm} \mathrm{Hg} \leq 150 \mathrm{~mm} \mathrm{Hg} \text { and for } \\
\text { every } 10 \mathrm{~mm} \mathrm{Hg}>150 \mathrm{~mm} \mathrm{Hg}(\mathrm{U} \text {-shaped relationship) } \\
\text { (b) increased SBP associated with } 14 \text {-day stroke recurrence (linear } \\
\text { relationship) }\end{array}$ \\
\hline $\begin{array}{l}\text { Aslanyan } \\
\text { et al. [82] }\end{array}$ & 2003 & 1,455 & $\begin{array}{l}\text { repeated recordings } \\
\text { over } 60.25 \mathrm{~h} \text { following } \\
\text { admission ( }<6 \text { h of ictus) }\end{array}$ & manual & $\begin{array}{l}\text { increased weighted average MAP associated with } 3 \text {-month } \mathrm{M} \text {, poor } \\
\text { neurological (NIHSS) and functional status (BI) at } 1 \text { month (linear } \\
\text { relationship)* }\end{array}$ \\
\hline $\begin{array}{l}\text { Oliveira-Filho } \\
\text { et al. [25] }\end{array}$ & 2003 & 115 & $\begin{array}{l}\text { repeated recordings over } \\
24 \mathrm{~h} \text { following admission } \\
(<24 \mathrm{~h} \text { of ictus) }\end{array}$ & manual & $\begin{array}{l}\text { SBP reduction within } 24 \text { h following admission was associated with } \\
\text { increased } 3 \text {-month M/D (linear relationship)* }\end{array}$ \\
\hline $\begin{array}{l}\text { Robinson } \\
\text { et al. [69] }\end{array}$ & 2003 & 124 & admission $(<24 \mathrm{~h})$ & $\begin{array}{l}\text { manual and } \\
\text { ABPM }\end{array}$ & $\begin{array}{l}\text { no association between admission and 24-hour BP and 1-month } \\
\text { M/D }\end{array}$ \\
\hline $\begin{array}{l}\text { Semplicini } \\
\text { et al. }[83]\end{array}$ & 2003 & 92 & $\begin{array}{l}\text { repeated recordings over } \\
7 \text { days following admission } \\
\text { ( }<6 \text { h of ictus) }\end{array}$ & manual & $\begin{array}{l}\text { increased admission MAP was associated with better neurological } \\
\text { outcome (NIHSS-score) at } 1 \text { week (linear relationship)* }\end{array}$ \\
\hline $\begin{array}{l}\text { Vlcek et al. } \\
\text { [84] }\end{array}$ & 2003 & 372 & $\begin{array}{l}\text { preadmission, admission } \\
\text { ( }<48 \mathrm{~h} \text { of ictus), 1st day } \\
\text { of ictus }\end{array}$ & manual & $\begin{array}{l}\text { DBP decrease }>25 \% \text { during the } 1 \text { st day was associated with increased } \\
\text { D at day } 5\end{array}$ \\
\hline $\begin{array}{l}\text { Castillo et al. } \\
{[25]}\end{array}$ & 2004 & 304 & $\begin{array}{l}\text { repeated recordings over } \\
7 \text { days following admission } \\
\text { ( }<24 \text { h of ictus) }\end{array}$ & manual & $\begin{array}{l}\text { reduction in SBP }>20 \mathrm{~mm} \mathrm{Hg} \text { within } 24 \mathrm{~h} \text { following admission was } \\
\text { associated with early }(<48 \mathrm{~h}) \text { neurological deterioration (CSS), } \\
\text { increased infarct volume and } 3 \text {-month } \mathrm{M}\end{array}$ \\
\hline $\begin{array}{l}\text { Vemmos } \\
\text { et al. [44] }\end{array}$ & 2004 & 930 & admission $(<24 \mathrm{~h})$ & manual & $\begin{array}{l}\text { 1-month M increased for different SBP levels below and above } 121- \\
140 \mathrm{~mm} \mathrm{Hg} \text { and for different DBP levels below and above } 81-90 \mathrm{~mm} \\
\mathrm{Hg} \text { (U-shaped relationship) }\end{array}$ \\
\hline $\begin{array}{l}\text { Okumura } \\
\text { et al. }[45]\end{array}$ & 2005 & 1,004 & admission $(<24 \mathrm{~h})$ & manual & $\begin{array}{l}\text { 1-month M increased for different SBP levels below and above 150- } \\
169 \mathrm{~mm} \mathrm{Hg} \text { and for different DBP levels below and above 100- } \\
109 \mathrm{~mm} \mathrm{Hg} \text { (U-shaped relationship) }\end{array}$ \\
\hline $\begin{array}{l}\text { Rodriguez- } \\
\text { Garcia et al. } \\
{[85]}\end{array}$ & 2005 & 434 & $\operatorname{admission}(<24 \mathrm{~h})$ & $\begin{array}{l}\text { manual and } \\
\text { ABPM }\end{array}$ & $\begin{array}{l}\text { (a) } 24 \text {-hour SBP }>160 \mathrm{~mm} \mathrm{Hg} \text { was associated with increased M/D } \\
\text { at } 1 \text { week } \\
\text { (b) SBP reduction }>5 \mathrm{~mm} \mathrm{Hg} \text { at day } 7 \text { was associated with functional } \\
\text { improvement (mRS) }\end{array}$ \\
\hline $\begin{array}{l}\text { Stead et al. } \\
{[86]}\end{array}$ & 2005 & 357 & $\begin{array}{l}\text { emergency department } \\
(<24 \mathrm{~h})\end{array}$ & manual & $\begin{array}{l}\mathrm{SBP}<155 \mathrm{~mm} \mathrm{Hg}(\mathrm{vs} .155-220 \mathrm{~mm} \mathrm{Hg}), \mathrm{DBP}<70 \mathrm{~mm} \mathrm{Hg} \text { (vs.70- } \\
105 \mathrm{~mm} \mathrm{Hg} \text { ), MAP }<100 \mathrm{~mm} \mathrm{Hg} \text { (vs.100-140 mm Hg) associated } \\
\text { with 3-month M }\end{array}$ \\
\hline
\end{tabular}

Studies including both patients with IS and ICH that did not analyse separately the relationship of acute BP with outcome for each stroke subtype were excluded.

$\mathrm{ABPM}=$ Ambulatory blood pressure monitoring (intermittent oscillometric recordings); $\mathrm{BI}=$ Barthel index; CNS = Canadian neurological scale; NIHSS = National Institutes of Health Stroke Scale; D = dependency (assessed by the modified Rankin scale, mRS); M = mortality.

${ }^{*} \mathrm{BP}$ data were entered in the analyses as continuous variables; ${ }^{* *}$ only the placebo-treated patients were included in the present table; ${ }^{* * *}$ non-invasive beat-to-beat blood pressure monitoring was used. 
Table 2. Observational studies investigating the relationship between initial blood pressure (BP) values and short-term outcome ( $\leq 3$ months) in patients with acute intracerebral haemorrhage (ICH)

\begin{tabular}{|c|c|c|c|c|c|}
\hline Study & Year & $\mathrm{n}$ & BP timing & BP method & Results \\
\hline $\begin{array}{l}\text { Dunne } \\
\text { et al. [87] }\end{array}$ & 1987 & $\begin{array}{l}75 \\
(\mathrm{CBL})\end{array}$ & admission & not given & $\mathrm{SBP}>200$ associated with 6-day M/D \\
\hline $\begin{array}{l}\text { Broderick } \\
\text { et al. [88] }\end{array}$ & 1993 & 188 & admission & not given & no association between admission $\mathrm{BP}$ and 1-month $\mathrm{M}$ \\
\hline $\begin{array}{l}\text { Carlberg } \\
\text { et al. [75] }\end{array}$ & 1993 & 85 & admission (<1 week) & manual & $\begin{array}{l}\text { (a) patients with impaired consciousness: Increased MAP } \\
\text { was associated with 1-month M (linear relationship)* } \\
\text { (b) alert patients: no association between BP and outcome }\end{array}$ \\
\hline $\begin{array}{l}\text { Dandapani } \\
\text { et al. [89] }\end{array}$ & 1995 & 87 & $\begin{array}{l}\text { repeated recordings over } \\
6 \mathrm{~h} \text { following admission }\end{array}$ & not given & $\begin{array}{l}\text { (a) MAP }>145 \mathrm{~mm} \mathrm{Hg}(0-2 \mathrm{~h}) \text { was associated with } \\
\text { 1-month } \mathrm{M} \\
\text { (b) MAP }>125 \mathrm{~mm} \mathrm{Hg}(2-6 \mathrm{~h}) \text { was associated with } \\
\text { 1-month M }\end{array}$ \\
\hline $\begin{array}{l}\text { Qureshi } \\
\text { et al. [90] }\end{array}$ & 1995 & 182 & emergency department & manual & $\begin{array}{l}\text { no association between MAP and early deterioration or } \\
\text { in-hospital M }\end{array}$ \\
\hline $\begin{array}{l}\text { Folgelholm } \\
\text { et al. [91] }\end{array}$ & 1997 & $\begin{array}{l}282 \\
(\mathrm{SPT})\end{array}$ & $\begin{array}{l}\text { repeated recordings over } \\
\text { the first } 24 \mathrm{~h}\end{array}$ & manual & $\begin{array}{l}\text { increased MAP was associated with 28-day M (linear } \\
\text { relationship)* }\end{array}$ \\
\hline $\begin{array}{l}\text { Terayama } \\
\text { et al. [92] }\end{array}$ & 1997 & 1,701 & admission $(<24 \mathrm{~h})$ & not given & $\begin{array}{l}\text { (a) thalamic and putaminal PICH = higher MAP in } \\
\text { patients who died during hospitalization } \\
\text { (b) subcortical, pontine and CBL PICH: no association } \\
\text { between MAP and outcome }\end{array}$ \\
\hline $\begin{array}{l}\text { Leira } \\
\text { et al. [93] }\end{array}$ & 2004 & $\begin{array}{l}266 \\
(\mathrm{SPT})\end{array}$ & $\begin{array}{l}\text { repeated recordings over } \\
\text { the first } 48 \mathrm{~h} \text { following } \\
\text { admission }(<12 \mathrm{~h})\end{array}$ & manual & $\begin{array}{l}\text { (a) increased highest SBP associated with early (within } \\
\text { first } 48 \mathrm{~h} \text { ) neurological deterioration (CSS, linear relation- } \\
\text { ship) }{ }^{*} \\
\text { (b) no association between BP and D }\end{array}$ \\
\hline $\begin{array}{l}\text { Vemmos } \\
\text { et al. [44] }\end{array}$ & 2004 & 191 & admission $(<24 \mathrm{~h})$ & manual & $\begin{array}{l}\text { 1-month } \mathrm{M} \text { increased for different SBP levels below and } \\
\text { above } 141-160 \mathrm{~mm} \mathrm{Hg} \text { and for different DBP levels below } \\
\text { and above } 101-110 \mathrm{~mm} \mathrm{Hg} \text { (U-shaped relationship) }\end{array}$ \\
\hline $\begin{array}{l}\text { Okumura } \\
\text { et al. [45] }\end{array}$ & 2005 & 1,097 & $\operatorname{admission}(<24 \mathrm{~h})$ & manual & $\begin{array}{l}\text { 1-month } \mathrm{M} \text { increased for different SBP levels below and } \\
\text { above } 150-169 \mathrm{~mm} \mathrm{Hg} \text { (J-shaped relationship) and for } \\
\text { different DBP levels below and above } 90-99 \mathrm{~mm} \mathrm{Hg} \\
\text { (U-shaped relationship) }\end{array}$ \\
\hline
\end{tabular}

Studies including both patients with IS and ICH that did not analyse separately the relationship of acute BP with outcome for each stroke subtype were excluded.

$\mathrm{BI}=$ Barthel index; $\mathrm{CBL}=$ cerebellar; STN = supratentorial CSS = Canadian stroke scale; $\mathrm{D}=$ dependency (assessed by the modified Rankin scale, mRS); $\mathrm{M}=$ mortality.

${ }^{*}$ BP data was entered in the analyses as continuous variables.

\section{Results}

\section{Lowering Blood Pressure in Acute Stroke}

\section{Contras}

Ischaemic Stroke

There is a series of arguments against treating hypertension in IS: (1) In the natural course of the disease BP values tend to normalise spontaneously within hours or days after IS onset [7, 13, 21, 22]. (2) Since the rescue of tissue at risk remains the main goal of acute IS treatment, keeping tissue perfusion pressure above a critical level within the ischaemic penumbra becomes of crucial importance. It is well known that cerebral autoregulation normally maintains perfusion over a wide range of systemic BP (fig. 1) and its curve is shifted towards higher BP values in chronic hypertensive individuals. During the acute phase of IS, cerebral autoregulation becomes dysfunctional and perfusion tends to be passively dependent on perfusion pressure [23]. Hence, it has been reasoned that BP should not be actively lowered in order to avoid any further reduction of the cerebral blood flow, with the possible sequelae of infarct extension and worsening of outcome $[15,24]$. The degree of BP reduction in the first 


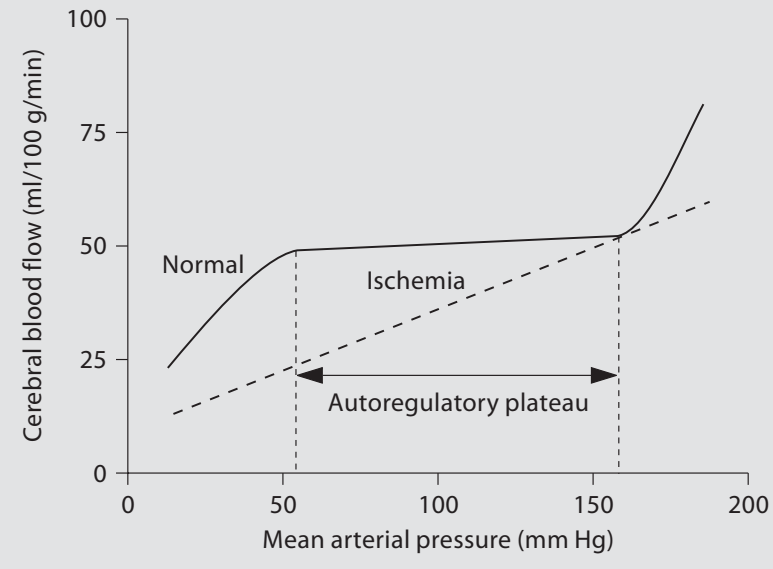

Fig. 1. Relationship between cerebral blood flow and mean arterial pressure under normal conditions and in ischaemia.

$24 \mathrm{~h}$ after stroke onset was independently associated with poor outcome in a series of patients with IS, who received antihypertensive treatment (59\%) in the emergency department [25]. Moreover, it has been recently reported that a BP drop $>20 \mathrm{~mm} \mathrm{Hg}$ during the first hours of ictus, followed by the use of BP-lowering medications, was the most important prognostic factor for early neurological deterioration, increased infarct volume and mortality at 3 months [26]. Furthermore, the investigators of Intravenous Nimodipine West European Trial have demonstrated that aggressive BP reduction with high-dose intravenous nimodipine was associated with neurological worsening of acute stroke patients [27, 28]. The authors assumed that the profound DBP drop $(>20 \%)$ in patients with already altered autoregulation may cause a further decrease in cerebral perfusion pressure and regional blood flow with deterioration of collateral supply below the lethal thresholds in the area of the ischaemic penumbra. (3) The course of elevated systolic BP in patients undergoing intra-arterial thrombolysis is inversely associated with the degree of vessel recanalisation. In a recent study, Mattle et al. [29] reported that, in patients where thrombolysis succeeded to reopen the occluded vessel, which was responsible for tissue ischaemia, SBP declined significantly faster in comparison to cases where recanalisation had failed. Based on the former observations it may be postulated that $\mathrm{BP}$ elevation might be a compensatory reaction to persistent vessel occlusion.

\section{Intracerebal Haemorrhage}

The following arguments are in favour of not treating hypertension in the acute stage of ICH: (1) In the natural course of the disease increased BP declines to baseline values within the first days after ICH onset $[7,30]$. (2) A zone of hypoperfusion in brain surrounding acute ICH has been reported in positron emission tomography (PET) studies $[31,32]$. Consequently, it has been argued that overaggressive BP reduction has the potential to further decrease the cerebral perfusion pressure and theoretically worsen brain injury particularly in the setting of increased intracranial pressure [23]. The findings of a single-photon emission CT (SPECT) study demonstrating that drug-induced reductions of mean arterial pressure (MAP) in excess of $20 \%$ during the acute period of the ICH resulted in a decrease of regional cerebral blood flow $(\mathrm{rCBF})$ are in keeping with the former hypothesis [33].

\section{Pros}

Ischaemic Stroke

The following arguments support the therapeutic manipulation of BP in the acute IS stage: (1) High BP levels in acute IS have been associated with subsequent death or dependency in a recent meta-analysis of observational studies investigating the association of BP with outcome [19]. (2) Sustained high BP values, assessed by means of ambulatory blood pressure monitoring have been associated with subsequent oedema formation [34], whereas casually documented elevated BP values have also been related to death resulting from presumed cerebral oedema in acute IS patients according to the results of the International Stroke Trial (IST) [35]. (3) Data from observational studies have suggested that increased admission BP values are related to early $[35,36]$ and late $[37,38]$ stroke recurrence.

\section{Intracerebal Haemorrhage}

Antihypertensive treatment is considered in patients with acute ICH on the basis of the subsequent arguments: (1) High BP levels in acute ICH have been associated with subsequent death, death or dependency and death or deterioration in a recent meta-analysis of observational studies investigating the association of $\mathrm{BP}$ with outcome [19]. (2) Increased acute BP values assessed by means of ambulatory blood pressure monitoring have been associated with cerebral oedema in ICH patients [14]. (3) Elevated $\mathrm{BP}$ values during the acute stroke stage have been shown to increase the risk of haematoma enlargement in patients with ICH $[19,39,40]$. (4) High admission BP values during the acute stage of ICH have been related to an increased rate of recurrent haemorrhagic stroke [41]. 
The U-Shaped Relationship between Acute BP Values and Stroke Outcome

Ischaemic Stroke

Some of the former pathophysiological facts and study findings support on the one hand the thesis of not applying - or even discontinuing previously initiated - antihypertensive treatment in the acute phase of stroke in order to avoid further infarct expansion and tissue necrosis. On the other hand, there is solid evidence suggesting that moderate BP lowering might be beneficial by reducing the risk of oedema formation, haematoma enlargement and stroke recurrence, improving this way survival and clinical outcome. Because of these conflicting issues and the lack of unambiguous data, the appropriate evidence-based approach to post-stroke hypertension remains to be settled $[42,43]$.

The U-shaped relationship between acute $\mathrm{BP}$ values and IS outcome might be an explanation for the discrepancy of findings and arguments. The IST was the first to demonstrate a U-shaped relationship between baseline SBP and both early death and late death or dependency in patients with IS [35]. Both high and low SBP values were independent prognostic factors for poor clinical outcome. This seemed to be attributed to the higher rates of early recurrence and cerebral oedema among patients with high $\mathrm{BP}$, while low $\mathrm{BP}$ values ( $\mathrm{SBP}<120 \mathrm{~mm} \mathrm{Hg}$ ) in the acute stroke setting have been associated with a severe clinical stroke (total anterior circulation syndrome) and an excess of deaths due to coronary heart disease [35]. Additionally, both low and high admission SBP and DBP values have been related to increased infarct volume [26]. A similar U-shaped relationship between admission SBP and DBP levels and early mortality among patients with acute IS has also been documented by two recent studies $[44,45]$. The best outcome was observed in patients with normal or mildly elevated admission SBP (U point or nadir of the curve: $121-170 \mathrm{~mm} \mathrm{Hg}$ ) and DBP values (U point or nadir of the curve: $81-110 \mathrm{~mm} \mathrm{Hg}$ ), suggesting that both extremely high and low admission $\mathrm{BP}$ values are likely to affect outcome adversely.

\section{Intracerebal Haemorrhage}

The U-shaped curve relating acute $\mathrm{BP}$ values with outcome has also been confirmed in patients with ICH according to the results of a Greek [44] and a Japanese [45] hospital-based study, which demonstrated that both lower and higher BP levels following ICH were predictors for poor early prognosis.

\section{Interpretation of Existing Trial Data}

Ischaemic Stroke

Unfortunately, solid data from randomised controlled trials (RCTs) are limited and inconclusive when considering whether lowering BP during the first hours of ictus is beneficial or not in IS patients. More specifically no randomised data exist for central acting agents, alpha adrenergic receptor blockers or other vasodilators, such as hydralazine. The efficacy and safety of transdermal nitric oxide donors has been demonstrated by a small RCT that studied transdermal glyceryl trinitrate and found that it lowered BP by $5-8 \%$ in a stroke population that mainly consisted of patients with recent IS (33 of the 37 cases) [46]. A recent pilot RCT concluded that following acute IS, oral benflurazide, a thiazide diuretic, did not lower systemic BP levels over the subsequent 7-day period [47].

Though the Perindopril Protection Against Recurrent Stroke Study [48] and the Heart Outcomes Prevention Evaluation-HOPE [49] have evaluated the efficacy of perindopril and ramipril, respectively, in the risk reduction of recurrent stroke in patients with cerebrovascular disease, neither of these studies provides information that might help us to determine how acutely following stroke the angiotensin-converting enzyme inhibitors can be commenced safely. One small RCT found that oral perindopril reduced BP values by $11 \%$ without altering global cerebral blood flow or middle cerebral artery (MCA) blood flow velocity [50]. The Acute Candesartan Cilexetil Therapy in Stroke Survivors - ACCESS, a prospective double-blind, placebo-controlled, randomised phase II trial, evaluated the use of an angiotensin II receptor blocker in acute IS patients with severely elevated BP levels (SBP >180 mm Hg and/or DBP >105 mm Hg). Preliminary data from 342 patients demonstrated that oral candesartan reduced a composite secondary outcome (allcause mortality and vascular events) by $52.5 \%$ [51]. It should be noted though that the trial was stopped prematurely with a neutral finding for its primary outcome (total mortality and disability at 3 months). Moreover, this preliminary observation remains to be confirmed by a larger phase III RCT [52].

In contrast, beta-blockers, such as propranolol and atenolol achieve a greater BP fall compared to placebo, but are characterised by a trend towards a worse outcome [20, 53]. The safety and feasibility of labetalol, a combined beta- and alpha-adrenergic antagonist, in rapidly and effectively reducing $\mathrm{BP}$ has been demonstrated in the NINDS thrombolysis trial [54]. Finally, the application of calcium channel antagonists during the acute stage of IS has no positive or negative effect on functional outcome 
or survival, according to a review of 29 RCTs [55] and the conclusions of a review from the Blood Pressure in Acute Stroke Collaboration (BASC) [20]. In addition, the INWEST trial demonstrated that the functional outcome was worsened in parallel with the degree by which $\mathrm{BP}$ was reduced $[27,28]$.

\section{Intracerebal Haemorrhage}

The existing trial data in the ICH subgroup is even scarcer. In a small survey of 10 critically ill haemorrhagic stroke patients ( 7 cases with ICH and 3 cases of subarachnoid haemorrhage) treated in a surgical intensive unit labetalol infusion produced a rapid and mild BP-lowering effect (SBP reduction ranging between 6 and 19\%, DBP reduction ranging between 3 and 26\%). This response did not worsen perceived mental status or stroke-induced neurologic deficits [56]. Nishiyama et al. [57] determined the effect of nicardipine infusion (titrated to maintain SBP levels between $120-160 \mathrm{~mm} \mathrm{Hg}$ ) on intracranial pressure, MCA flow velocity as well as the presence of brain oedema and haematoma rebleeding in 22 patients with putaminal $\mathrm{ICH}$ after surgical evacuation. Intracranial pressure decreased during the infusion without any change in MCA velocity or any evidence of rebleeding and exacerbation of cerebral oedema. Powers et al. [58] had also evaluated the impact of BP reduction in 14 patients with acute $(6-22 \mathrm{~h}$ after onset) supratentorial ICH on $\mathrm{rCBF}$ measured by means of PET scan. MAP was reduced by $15 \%$ using either nicardipine or labetalol infusions. Interestingly, no significant difference in the perihaematomal $\mathrm{rCBF}$ or global CBF before and after treatment was observed. Lastly, Qureshi et al. [59] performed a multicenter prospective observational study to evaluate the feasibility and safety of intravenous antihypertensive protocol (infusion of labetalol and/or hydralazine and/or nitroprusside) for controlling SBP and DBP levels below 160 and $90 \mathrm{~mm} \mathrm{Hg}$, respectively, in 27 patients with acute $\mathrm{ICH}$. The investigators documented a low rate of neurological deterioration (7.4\%) and haematoma expansion (9.1\%) in the treated patients. Furthermore, they noted that patients treated within $6 \mathrm{~h}$ from symptom onset were more likely to be functionally independent at 1 month compared with cases who were treated during the time window between 6 and $24 \mathrm{~h}$

\section{Ongoing Trials}

The results of currently ongoing trials may provide some answers to some of the former unresolved issues. The Control of Hypertension and Hypotension Immediately Post-Stroke Trial [60] is a randomised double-blind placebo-controlled study using stepwise angiotensin-converting enzyme inhibitors. Death and dependency at 2 weeks after stroke will be the primary outcome measure. The transdermal application of glyceryl trinitrate is evaluated in the Efficacy of Nitric Oxide in Stroke - ENOS study [61]. Useful data about stroke patients who are already on antihypertensive medication are expected from the Continue or Stop Post-Stroke Antihypertensive Collaborative Study [62].

\section{Raising Blood Pressure in Acute Stroke}

\section{Ischaemic Stroke}

Feasibility, Safety and Preliminary Results of Induced BP Elevation. If BP lowering in the acute setting of stroke could have detrimental results, it could than be theoretically assumed that raising BP might be beneficial, especially in terms of saving tissue in the ischaemic penumbra. However, there is scarce randomised or observational evidence to support this practice. Rodorf et al. $[63,64]$ have reported that intravenous application of phenylephrine is safe and feasible based on the findings of two small pilot studies. Moreover, the investigators noted that the responders to vasopressors scored better in the NIHSS at discharge [64]. Norepinephrine infusion has also been used to induce hypertension in 19 acute IS patients with complete or subtotal MCA stroke and was associated with enhanced cerebral perfusion without any detrimental increases in intracranial pressure [65].

Selection of Candidate Patients for Induced BP Elevation. The results of a preliminary study showed that patients who were most likely to display functional gains with pressor therapy, were those with severe stenosis or occlusion of an internal carotid artery (ICA) and/or a MCA [64]. It is conceivable that induced BP elevation could be more beneficial in such cases, since the former stroke subgroup is the most likely to present with the largest perfusion-diffusion mismatch during the first hours of ictus. Furthermore, in an ambulatory BP-monitoring study that evaluated the early spontaneous time course of BP in IS subgroups of different etiology, a substantially steeper BP decline was documented in the large-arteryatherosclerotic stroke subgroup [14]. Finally, according to a recent pilot RCT pharmacological BP elevation in patients with acute IS and large perfusion-diffusion mismatch caused by occlusion or stenosis of ICA and/or MCA resulted in smaller tissue lesions, as these were visualised by means of perfusion weighted MRI on the third day after stroke onset [66]. The previous encouraging 
findings warrant a full-scale double-blind clinical trial to investigate the efficacy and risks of this type of intervention specifically in the subgroup of patients with carotid artery disease.

\section{Intracerebal Haemorrhage}

To the best of our knowledge no study had previously addressed the issue of raising low or normal BP levels in the setting of acute $\mathrm{ICH}$.

\section{Discussion}

\section{Limitations and Shortcomings of Observational} Studies

The discrepancies between the results of the various observational studies may reflect underlying methodological problems such as BP levels measured by different observers, retrospective BP documentation and lack of data on how BP was recorded. As illustrated in tables 1 and 2 , the variation in the time of BP measurements (ranging from a few hours to several days after stroke onset) may also account in part for the conflicting results. In addition, certain reports did not investigate the relationship of acute BP levels with stroke outcome separately in the IS and the ICH subgroup, others used highly selected patient groups participating in clinical trials $[27,28]$, while some investigators continued or initiated BP-lowering medications following admission $[25,26]$. Furthermore, the study protocol of certain reports did not include CT scans routinely in all stroke patients $[7,67]$, while in a number of studies unconscious stroke patients and cases with atrial fibrillation were excluded [67-69]. Besides, functional disability and neurological impairment were evaluated by different outcome measures in the majority of the observational studies (tables 1,2). Finally, in the IST, which is the study that involved by far the largest cohort of patients $(\mathrm{n}=17,398)$, only a single measure of SBP was available for each patient [35]. Consequently, the relationship of $\mathrm{DBP}$ and its derivatives (MAP, pulse pressure) with outcome could not be evaluated.

\section{Limitations and Shortcomings of Intervention Trials} Ischaemic Stroke

Certain limitations of the pilot trials that assessed antihypertensive treatment strategies in acute IS patients are worth pondering. For one, the time window for randomisation ranged from 24 [51] to $120 \mathrm{~h}$ [46] following stroke onset in these preliminary intervention studies. Consequently, the different degrees of $\mathrm{BP}$ reduction document- ed in the various antihypertensive drug classes should be acknowledged after taking into account the former confounder. Moreover, only in the ACCESS study all subjects received carotid ultrasound examination before randomisation, which resulted in the exclusion of subjects with severe stenosis and occlusion of the ICA [51]. Since patients with carotid artery disease present the highest perfusion-diffusion mismatch, even moderate $\mathrm{BP}$ reductions may result in substantial reductions in $\mathrm{CBF}$ and cause infarct expansion [24]. This safety issue should be taken into consideration in the design of future phase III trials. It is also noteworthy that during the placebo-controlled phase of the ACCESS study in the first 7 days following recruitment, BP levels were similar in patients treated with angiotensin II receptor blockers and patients receiving placebo. Consequently, the authors assumed that the beneficial effect of candesartan could be attributed to its neurohumoral inhibiting effects [51]. Further research is needed to resolve the underlying mechanisms by which angiotensin receptor blockers affect the cerebrovascular system. Finally, Doppler data in the majority of intervention trials $[47,50]$ support the hypothesis that a number of BP-lowering medications does not adversely affect CBF or alter cerebral haemodynamics in a clinically significant way. Other forms of brain imaging techniques such as SPECT or PET scanning are needed to further validate the previous findings and provide additional information on the effects of BP-lowering treatment on regional perfusion, particularly in the area surrounding the cerebral infarct.

Limited preliminary trials seem to support the alternative therapeutic approach of induced hypertension in specific subgroups of acute IS patients. Nevertheless, there are important arguments against raising BP during the acute IS stage. Although, drug-induced hypertension holds promise, this therapy may be associated with increased risk of brain oedema or haemorrhagic transformation of the cerebral infarction, while additional vasopressor-related complications may include cardiac ischaemia or arrhythmias [52]. Furthermore, it should be acknowledged that sympathomimetic agents tend to induce platelet activation, while it is noteworthy that the use of such drugs within nasal decongestants and in weight reduction programmes has been associated with the development of stroke and other vascular diseases [70]. Lastly, certain agents which raise BP (although this was not their intended effect) had unfavourable effects on stroke outcome in RCTs during the acute stroke period. More specifically, the administration of diaspirin cross-linked haemoglobin has been associated with raised BP levels during the first three days of ictus and worse outcome [71]. 
Table 3. Current guidelines for the management of blood pressure in the acute phase of ischaemic stroke

\begin{tabular}{|c|c|}
\hline BP level, mm Hg & Treatment \\
\hline \multicolumn{2}{|c|}{ Stroke Council of the American Stroke Association $[43,52]$} \\
\hline $\mathrm{SBP} \leq 220$ or $\mathrm{DBP} \leq 120$ & $\begin{array}{l}\text { (a) defer antihypertensive therapy } \\
\text { (b) drug-induced hypertension is not recommended for } \\
\text { the treatment of most patients. }\end{array}$ \\
\hline \multirow[t]{2}{*}{$\mathrm{SBP}>220$ or $121<\mathrm{DBP}<140$} & $\begin{array}{l}\text { (i) labetalol 10-20 mg i.v. over 1-2 min, may repeat or } \\
\text { double every } 10 \mathrm{~min} \text { (maximum } 300 \mathrm{mg} \text { ) }\end{array}$ \\
\hline & $\begin{array}{l}\text { (ii) nicardipine } 5 \mathrm{mg} / \mathrm{h} \text { i.v. infusion as initial dose, titrate } \\
\text { to desired effect by increasing } 2.5 \mathrm{mg} / \mathrm{h} \text { every } 5 \mathrm{~min} \\
\text { (maximum } 15 \mathrm{mg} / \mathrm{h} \text { ) } \\
\text { target: } 10-15 \% \text { reduction of } \mathrm{BP}\end{array}$ \\
\hline $\mathrm{DBP}>140$ & $\begin{array}{l}\text { (i) nitroprusside } 0.5 \mu \mathrm{g} / \mathrm{kg} / \mathrm{min} \text { as initial dose with con- } \\
\text { tinuous BP monitoring } \\
\text { target } 10-15 \% \text { reduction of BP }\end{array}$ \\
\hline \multirow{2}{*}{\multicolumn{2}{|c|}{ European Stroke Initiative [72] }} \\
\hline & \\
\hline $105<\mathrm{DBP}<140$ & defer antihypertensive therapy \\
\hline \multirow{2}{*}{$\begin{array}{l}\mathrm{SBP}>220 \text { or } 121<\mathrm{DBP}<140 \\
\text { on repeated measures }\end{array}$} & (i) labetalol 5-20 mg i.v. \\
\hline & $\begin{array}{l}\text { (ii) uradipil } 10-50 \mathrm{mg} \text { i.v., followed by } 4-8 \mathrm{mg} / \mathrm{h} \text { i.v. } \\
\text { (iii) captopril } 6.25-12.5 \mathrm{mg} \text { p.o. or i.m. } \\
\text { (iv) clonidine } 0.15-0.30 \mathrm{mg} \text { i.v. or s.c. } \\
\text { (v) dihydralazine } 5 \mathrm{mg} \text { i.v. plus metoprolol } 10 \mathrm{mg}\end{array}$ \\
\hline \multirow[t]{2}{*}{$\mathrm{DBP}>140$} & (i) sodium nitroprusside $1-2 \mathrm{mg}$ \\
\hline & (ii) nitroglycerin $5 \mathrm{mg}$ i.v., followed by $1-4 \mathrm{mg} / \mathrm{h}$ i.v. \\
\hline
\end{tabular}

Intracerebal Haemorrhage

Certain important methodological issues should be addressed before interpreting the results of the trials that investigated the feasibility of BP-lowering medications in the setting of acute ICH. First, the rates of neurological deterioration and haematoma expansion were compared to unmatched patients with variable characteristics. Therefore, no direct comparisons can be made. Second, the small number of patients enrolled in the former studies raises concerns regarding the safety of aggressive pharmacological treatment of acute hypertension, especially after taking into consideration that nicardipine infusion was associated with decreased cerebral perfusion pressure in one trial [57], although the former reduction did not correlate with a poorer outcome. Third, there is a possibility that asymptomatic haematoma expansion may be undetected in certain cases, since repeat CT scans were not acquired consistently but at the discretion of treating physicians and were usually performed only in patients with clinical deterioration [59].

\section{Recommendations - Conclusions}

Ischaemic Stroke

The European Stroke Initiative (EUSI) [72] and the Stroke Council of the American Stroke Association [43,
52] have released updated scientific statements and guidelines regarding the management of hypertension in the setting of acute IS. Both authorities recommend that BP should not be lowered in IS patients who are not otherwise candidates for thrombolysis (grade $\mathrm{C}$ recommendation; supported by data from non-randomised concurrent cohort studies with historical controls or anecdotal case series). Threshold BP values demanding immediate medical interventions are recommended by consensus (table 3). More specifically, pharmacological intervention is indicated if repeated BP readings reveal SBP values $>220 \mathrm{~mm} \mathrm{Hg}$ and DBP >120 mm Hg. In patients eligible for thrombolytic therapy SBP values $>185 \mathrm{~mm} \mathrm{Hg}$ or DBP values $>110 \mathrm{~mm} \mathrm{Hg}$ should be actively treated and maintained at desired levels $(<185 / 110 \mathrm{~mm} \mathrm{Hg})$ during and after rt-PA infusion. Situations that might require urgent antihypertensive therapy independent of BP levels include acute myocardial infarction, severe left ventricular heart failure, aortic dissection, acute renal failure, acute pulmonary oedema and hypertensive encephalopathy (table 4).

In cases where acute therapeutic manipulation of $\mathrm{BP}$ is indicated, BP lowering should be done cautiously at a clinically significant and relevant degree (target of BP reduction ranging from 10 to $15 \%$ ), in order to avoid profound 
$(>20 \%)$ BP reductions that have been associated with neurological and functional worsening [27]. Parenteral agents such as labetalol, nicardipine or uradipil that are easily titrated and have minimal vasodilatory effects on cerebral blood flow are preferred (table 3 ). In certain cases with excessive DBP levels ( $>140 \mathrm{~mm} \mathrm{Hg}$ ), intravenous administration of sodium nitroprusside is recommended for adequate BP control, despite possible major adverse effects, such as reflex tachycardia and coronary artery ischaemia. The use of sublingual nifedipine should be avoided because of the risk of abrupt BP reduction and possible ischaemic steel $[43,72]$. Finally, at present, drug-

Table 4. Indications for urgent antihypertensive therapy in patients with acute ischaemic stroke according to current guidelines

\begin{tabular}{ll}
\hline Authority & Urgent treatment indications \\
\hline Stroke Council of the American & $\begin{array}{l}\text { acute myocardial infarction } \\
\text { acute renal failure } \\
\text { aortic dissection } \\
\text { acute pulmonary oedema } \\
\text { hypertensive encephalopathy }\end{array}$ \\
\hline European Stroke Initiative [72] & $\begin{array}{l}\text { acute myocardial ischaemia } \\
\text { acute renal failure } \\
\text { aortic arch dissection } \\
\text { cardiac insufficiency }\end{array}$ \\
\hline
\end{tabular}

induced hypertension cannot be recommended for the treatment of most patients with IS [52].

\section{Intracerebal Haemorrhage}

Current recommendations for treatment of elevated BP levels in patients with acute ICH are more aggressive than those for cases with IS [42]. Accordingly, SBP and DBP levels should be maintained below 180 and $105 \mathrm{~mm}$ $\mathrm{Hg}$, respectively (table 5). If antihypertensive treatment is indicated during the acute stage of $\mathrm{ICH}$, then $\mathrm{BP}$ should be lowered carefully in a monitored setting with close and continuous observation of BP values and using an easily titrable, short-acting agent (such as labetalol, esmolol, enalapril or nicardipine). Theoretical concerns regarding the vasodilatory effects of sodium nitroprusside and its potential detrimental impact on intracranial pressure [73] limit its use only in patients with excessively high SBP $(>230 \mathrm{~mm} \mathrm{Hg})$ and DBP (>140 mm Hg) levels. Extreme $(>20 \%)$ reductions in BP levels ought to be avoided [32] and if SBP falls below $90 \mathrm{~mm} \mathrm{Hg}$ the use of pressors is indicated [42].

\section{Perspectives}

In the absence of solid data supporting the elevation or reduction of $\mathrm{BP}$ in patients with acute stroke, it is clear that evidence from RCTs is urgently required. These trials should have sufficient power and size to take into account:
Table 5. Current guidelines for the management of blood pressure in the acute phase of intracerebral haemorrhage [42]

\begin{tabular}{|c|c|}
\hline BP level, mm Hg & Treatment \\
\hline SBP $<90$ & $\begin{array}{l}\text { (a) volume replenishment (isotonic saline or } \\
\text { colloids) as first-line approach } \\
\text { (b) infusion of pressors (if hypotension persists } \\
\text { after correction of volume deficit) as second-line } \\
\text { approach: } \\
\text { (i) phenylephrine } 2-10 \mu \mathrm{g} / \mathrm{kg} / \mathrm{min} \text { i.v. } \\
\text { (ii) dopamine } 2-20 \mu \mathrm{g} / \mathrm{kg} / \mathrm{min} \text { i.v. } \\
\text { (iii) norepinephrine } 0.05-0.20 \mu \mathrm{g} / \mathrm{kg} / \mathrm{min} \text { i.v. }\end{array}$ \\
\hline $\mathrm{SBP}=91-179$ and $\mathrm{DBP}<105$ & defer antihypertensive therapy \\
\hline $\begin{array}{l}180<\mathrm{SBP}<230 \text { or } 105<\mathrm{DBP}<140 \\
(2 \text { readings } 20 \text { min apart })\end{array}$ & $\begin{array}{l}\text { (i) labetalol } 5-100 \mathrm{mg} \text { i.v. by intermittent bolus } \\
\text { doses of } 10-40 \mathrm{mg} \text { or continuous drip } \\
(2-8 \mathrm{mg} / \mathrm{min} \text { ) } \\
\text { (ii) esmolol } 500 \mu \mathrm{g} / \mathrm{kg} \text { i.v. loading dose; } \\
\text { maintenance use } 50-200 \mu \mathrm{g} / \mathrm{kg} / \mathrm{min} \\
\text { (iii) enalapril } 0.625-1.2 \mathrm{mg} \text { i.v. } \\
\text { (iv) other easily titratable i.v. medications } \\
\text { (diltiazem, lisinopril, verapamil, nicardipine) }\end{array}$ \\
\hline
\end{tabular}

SBP $>230$ or $\mathrm{DBP}>140$ (2 readings 5 min apart)

(i) nitroprusside $0.5-1.0 \mu \mathrm{g} / \mathrm{kg} / \mathrm{min}$ i.v.

cosing apt) 
(1) different patient groups according to age, gender, stroke subtypes; comorbidities; (2) different treatment paradigms (increase or decrease BP, drug class, timing and route of therapeutic BP manipulation, continue or temporarily stop prior antihypertensive medications); (3) different treatment effects of antihypertensive drug classes (BP reduction, neurohumoral inhibitory effects); (4) other acute stroke treatment strategies (thrombolysis);

(5) strict, clinically meaningful outcome measures, and
(6) safety issues. Smaller studies are also needed to investigate the impact of vasoactive drugs in pathophysiological mechanisms underlying stroke, such as cerebral perfusion and haemostasis. The anticipated results of the currently ongoing phase III trials may clarify certain of the former issues regarding the optimal BP management in acute stroke and provide adequate scientific basis for more evidence-based treatment decisions in the moderately near future.

\section{References}

1 Lewington S, Clarke R, Qizilbash N, Peto R, Collins R: Prospective studies collaboration: age-specific relevance of usual blood pressure to vascular mortality: a meta-analysis of individual data for one million adults in 61 prospective studies. Lancet 2002;360:1903-1913.

2 Chalmers J, Todd A, Chapman N, et al: International Society of Hypertension Writing Group. International Society of Hypertension Writing Group. International Society of Hypertension (ISH): statement on blood pressure lowering and stroke prevention. J Hypertens 2003;21:651-663.

-3 Donnan GA, Davis SM, Thrift A: The role of blood pressure lowering before and after stroke. Curr Opin Neurol 2003;16:81-86.

4 Rashid P, Leonardi-Bee J, Bath P: Blood pressure reduction and secondary prevention of stroke and other vascular events: a systematic review. Stroke 2003;34:2741-2748.

$\checkmark 5$ CAST (Chinese Acute Stroke Trial) Collaborative Group: (CAST: randomised placebocontrolled trial of early aspirin use in 20,000 patients with acute ischaemic stroke. Lancet 1997;349:1641-1649.

-6 International Stroke Trial Collaborative Group: The International Stroke Trial (IST): a randomised trial of aspirin, subcutaneous heparin, both, or neither among 19,435 patients with acute ischaemic stroke. Lancet 1997;349:1569-1581.

7 Britton M, Carlsson A, de Faire U: Blood pressure course in patients with acute stroke and matched controls. Stroke 1986;17:861-864.

-8 Myers MG, Norris JW, Hachniski VC, Sole MJ: Plasma norepinephrine in stroke. Stroke 1981;12:200-204.

-9 Olson T, Marklund N, Gustafson Y, Nasman B: Abnormalities at different levels of the hypothalamic-pituitary adrenocortical axis early after stroke. Stroke 1992;23:1573-1576.

10 Carlberg B, Asplund K, Hagg E: High blood pressure in acute stroke - is it white coat hypertension? J Intern Med 1990;228:291292.

11 Ito A, Omae T, Katsuki S: Acute changes in blood pressure following vascular diseases in the brain stem. Stroke 1973;4:80-84.
2 Harper G, Castleden CM, Potter JF: Factors affecting changes in blood pressure after acute stroke. Stroke 1994;25:1726-1729.

13 Vemmos KN, Tsivgoulis G, Spengos K, et al: Blood pressure course in acute ischaemic stroke varies in relation to stroke subtype. Blood Press Monit 2004;9:107-114.

14 Vemmos K, Spengos K, Tsivgoulis G, et al: Factors influencing acute blood pressure values in stroke subtypes. J Hum Hypertens 2004; 18:253-259.

15 Yatsu FM, Zivin J: Hypertension in acute ischemic strokes: not to treat. Arch Neurol 1985; 42:999-1000.

16 Spencer JD: Hypertension in acute ischemic stroke: to treat. Arch Neurol 1985;42:10001002.

17 Robinson TG, Potter JF: Blood pressure in acute stroke. Age Ageing 2004;33:6-12.

18 Bath P, Chalmers J, Powers W, et al: International Society of Hypertension Writing Group. International Society of Hypertension (ISH): statement on the management of blood pressure in acute stroke. J Hypertens 2003;21:665672.

19 Willmot M, Leonardi-Bee J, Bath PM: High blood pressure in acute stroke and subsequent outcome: a systematic review. Hypertension 2004;43:18-24.

20 Blood Pressure in Acute Stroke Collaboration (BASC): Interventions for deliberately altering blood pressure in acute stroke. Cochrane Database Syst Rev 2001:CD000039.

21 Broderick J, Brott T, Barsan W, et al: Blood pressure during the first minutes of focal cerebral ischemia. Ann Emerg Med 1993;22: 1438-1443.

22 Carlberg B, Asplund K, Hagg E: Course of blood pressure in different subsets of patients after acute stroke. Cerebrovasc Dis 1991;1: 281-287.

23 Powers WJ: Acute hypertension after acute stroke: the scientific basis for treatment decisions. Neurology 1993;43:461-467.
24 Fischberg GM, Lozano E, Rajamani K, Ameriso S, Fisher MJ: Stroke precipitated by moderate blood pressure reduction. J Emerg Med 2000;19:339-346.

25 Oliveira-Filho J, Silva SC, Trabuco CC, Pedreira BB, Sousa EU, Bacellar A: Detrimental effect of blood pressure reduction in the first $24 \mathrm{~h}$ of acute stroke onset. Neurology 2003;61: 1047-1051.

26 Castillo J, Leira R, Garcia MM, Serena J, Blanco M, Davalos A: Blood pressure decrease during the acute phase of ischemic stroke is associated with brain injury and poor stroke outcome. Stroke 2004;35:520-526.

27 Wahlgren NG, MacMahon DG, de Keyser J, Indredavik B, Ryman T, INWEST Study Group: Intravenous Nimodipine West European Stroke Trial (INWEST) of nimodipine in the treatment of acute ischaemic stroke. Cerebrovasc Dis 1994;4:204-210.

28 Ahmed N, Nasman P, Wahlgren NG: Effect of intravenous nimodipine on blood pressure and outcome after acute stroke. Stroke 2000; 31:1250-1255.

29 Mattle HP, Kappeler L, Arnold M, et al: Blood pressure and vessel recanalization in the first hours after ischemic stroke. Stroke 2005;36: 264-268.

30 Morfis L, Schwartz RS, Poulos R, Howes LG: Blood pressure changes in acute cerebral infarction and hemorrhage. Stroke 1997;28: 1401-1405.

31 Zazulia AR, Diringer MN, Videen TO, et al: Hypoperfusion without ischemia surrounding acute intracerebral hemorrhage. J Cereb Blood Flow Metab. 2001;21:804-810.

32 Videen TO, Dunford-Shore JE, Diringer MN, Powers WJ: Correction for partial volume effects in regional blood flow measurements adjacent to hematomas in humans with intracerebral hemorrhage: implementation and validation. J Comput Assist Tomogr 1999;23: 248-256.

33 Kuwata N, Kuroda K, Funayama M, Sato N, Kubo N, Ogawa A: Dysautoregulation in patients with hypertensive intracerebral hemorrhage: a SPECT study. Neurosurg Rev 1995; 18:237-245. 
34 Vemmos K, Tsivgoulis G, Spengos K, et al: Association between 24 -h blood pressure monitoring variables and oedema formation in patients with hyperacute stroke. J Hypertens 2003;21:2167-2173.

- 35 Leonardi-Bee J, Bath PM, Phillips SJ, Sandercock PA, IST Collaborative Group: Blood pressure and clinical outcomes in the International Stroke Trial. Stroke 2002;33:1315-1320.

- 36 Sacco RL, Foulkes MA, Mohr JP, Wolf PA, Hier DB, Price TR: Determinants of early recurrence of cerebral infarction. The Stroke Data Bank. Stroke 1989;20:983-989.

- 37 Hier DB, Foulkes MA, Swiontoniowski M, et al: Stroke recurrence within 2 years after ischaemic infarction. Stroke 1991;22:155-161.

- 38 Tsivgoulis G, Spengos K, Zakopoulos N, Manios E, Vassilopoulos D, Vemmos K: Twenty-four-hour pulse pressure predicts long-term recurrence in acute stroke patients. J Neurol Neurosurg Psychiatry 2005;76:1360-1365.

- 39 Kazui S, Minematsu K, Yamamoto H, Sawada T, Yamaguchi T: Predisposing factors to enlargement of spontaneous intracerebral hematoma. Stroke 1997;28:2370-2375.

40 Ohwaki K, Yano E, Nagashima H, Hirata M, Nakagomi T, Tamura A: Blood pressure management in acute intracerebral hemorrhage: relationship between elevated blood pressure and hematoma enlargement. Stroke 2004;35: 1364-1367.

-41 Arakawa S, Saku Y, Ibayashi S, Nagao T, Fujishima M: Blood pressure control and recurrence of hypertensive brain hemorrhage. Stroke 1998;29:1806-1809.

42 Broderick JP, Adams HP Jr, Barsan W, et al: Guidelines for the management of spontaneous intracerebral hemorrhage: a statement for healthcare professionals from a special writing group of the Stroke Council, American Heart Association. Stroke 1999;30:905-915.

-43 Adams HP Jr, Adams RJ, Brott T, et al: Stroke Council of the American Stroke Association. Guidelines for the early management of patients with ischemic stroke: A scientific statement from the Stroke Council of the American Stroke Association. Stroke 2003;34: 1056-1083.

44 Vemmos KN, Tsivgoulis G, Spengos K, et al: U-shaped relationship between mortality and admission blood pressure in patients with acute stroke. J Intern Med 2004;255:257-265.

-45 Okumura K, Ohya Y, Maehara A, Wakugami K, Iseki K, Takishita S: Effects of blood pressure levels on case fatality after acute stroke. J Hypertens 2005;23:1217-1223.

46 Bath PMW, Pathansali R, Iddenden R, Bath FJ: The effect of transdermal glyceryl trinitrate, a nitric oxide donor, on blood pressure and platelet function in acute stroke. Cerebrovasc Dis 2001;11:265-272.

-47 Eames PJ, Robinson TG, Panerai RB, Potter JF: Bendrofluazide fails to reduce elevated blood pressure levels in the immediate poststroke period. Cerebrovasc Dis 2005; 19:253259.
48 PROGRESS Collaborative Group: Randomised trial of a perindopril-based blood-pressurelowering regimen among 6,105 individuals with previous stroke or transient ischaemic attack. Lancet 2001;358:1033-1041.

49 Bosch J, Yusuf S, Pogue J, et al: HOPE Investigators. Heart outcomes prevention evaluation: use of ramipril in preventing stroke: double blind randomised trial. Br Med J 2002;324: 699-702.

50 Dyker AG, Grosset DG, Lees K: Perindopril reduces blood pressure but not cerebral blood flow in patients with recent cerebral ischemic stroke. Stroke 1997;28:580-583.

51 Schrader J, Luders S, Kulschewski A, et al: Acute Candesartan Cilexetil Therapy in Stroke Survivors Study Group (2003). The ACCESS Study: evaluation of acute candesartan cilexetil therapy in stroke survivors. Stroke 2003; 34:1699-1703.

52 Adams H, Adams R, Del Zoppo G, Goldstein LB: Stroke Council of the American Heart Association; American Stroke Association (2005). Guidelines for the early management of patients with ischemic stroke: 2005 guidelines update a scientific statement from the Stroke Council of the American Heart Association/American Stroke Association. Stroke 2005;36:916-923.

53 Barer DH, Cruickshank JM, Ebrahim SB, Mitchell JR: Low dose beta blockade in acute stroke ('BEST' trial): an evaluation. Br Med J 1998;296:737-741.

54 Brott T, Lu M, Kothari R, et al: Hypertension and its treatment in the NINDS rt-PA Stroke Trial. Stroke 1998;29:1504-1509.

55 Horn J, Limburg M: Calcium antagonists for ischemic stroke: a systematic review. Stroke 2001;32:570-576.

56 Patel RV, Kertland HR, Jahns BE, Zarowitz BJ, Mlynarek ME, Fagan SC: Labetalol: response and safety in critically ill hemorrhagic stroke patients. Ann Pharmacother 1993;27:180181.

57 Nishiyama T, Yokoyama T, Matsukawa T, Hanaoka K: Continuous nicardipine infusion to control blood pressure after evacuation of acute cerebral hemorrhage. Can J Anaesth 2000;47:1196-1201.

58 Powers WJ, Zazulia AR, Videen TO, et al: Autoregulation of cerebral blood flow surrounding acute (6 to $22 \mathrm{hs}$ ) intracerebral hemorrhage. Neurology 2001;57:18-24.

59 Qureshi AI, Mohammad YM, Yahia AM, et al: A prospective multicenter study to evaluate the feasibility and safety of aggressive antihypertensive treatment in patients with acute intracerebral hemorrhage. J Intens Care Med 2005;20:34-42.

60 Potter J, Robinson T, Ford G, et al: The CHHIPS Trial Group. CHHIPS (Controlling Hypertension and Hypotension Immediately Post-Stroke) Pilot Trial: rationale and design. J Hypertens 2005;23:649-655.
61 Bath PM, Willmot MR, Weaver C, LeonardiBee J: Efficacy of nitric oxid in stroke (ENOS) trial - a prospective randomised controlled trial in acute stroke. Cerebrovasc Dis 2002; 13(suppl 3):79.

62 COSSACS Trial Group: COSSACS (Continue or Stop Post-Stroke Antihypertensives Collaborative Study): rationale and design. J Hypertens 2005;23:455-458.

63 Rordorf G, Cramer SC, Efird JT, Schwamm LH, Buonanno FS, Koroshetz WJ: Pharmacological elevation of blood pressure in acute stroke: clinical effects and safety. Stroke 1997; 28:2133-2138.

64 Rordorf G, Koroshetz WJ, Ezzeddine MA, Segal AZ, Buonanno FS: A pilot study of drug induced hypertension for treatment of acute stroke. Neurology 2001;56:1210-1213.

- 65 Schwarz S, Georgiadis D, Aschoff A, Schwab $S$ : Effects of induced hypertension on intracranial pressure and flow velocities of the middle cerebral arteries in patients with large hemispheric stroke. Stroke 2002;33:9981004.

66 Hillis AE, Ulatowski JA, Barker BP, et al: A pilot randomized trial of induced blood pressure elevation: effects on function and focal perfusion in acute and subacute stroke. Cerebrovasc Dis 2003; 16:236-246.

67 Robinson T, Waddington A, Ward-Close S, Taub N, Potter J: The predictive role of 24hour compared to casual blood pressure levels on outcome following acute stroke. Cerebrovasc $\mathrm{Dis}$ 1997;7:264-272.

68 Dawson SL, Manktelow BN, Robinson TG, Panerai RB, Potter JF: Which parameters of beat-to-beat blood pressure and variability best predict early outcome after acute ischemic stroke? Stroke 2000;31:463-468.

69 Robinson TG, Dawson SL, Eames PJ, Panerai RB, Potter JF: Cardiac baroreceptor sensitivity predicts long-term outcome after acute ischemic stroke. Stroke 2003;34:705-712.

70 Kernan WN, Viscoli CM, Brass LM, et al: Phenylpropanolamine and the risk of hemorrhagic stroke. N Engl J Med 2000;43:18261832.

71 Saxena R, Wijnhoud AD, Carton $\mathrm{H}$, et al: Controlled safety study of a hemoglobinbased oxygen carrier, DCLHb, in acute ischemic stroke. Stroke 1999;20:993-996.

72 Hacke W, Kaste M, Bogousslavsky J, et al: European Stroke Initiative Executive Committee and the EUSI Writing Committee. European Stroke Initiative Recommendations for Stroke Management - Update 2003. Cerebrovasc Dis 2003;16:311-337.

73 Cottrell JE, Patel K, Turndorf H, Ransohoff J: Intracranial pressure changes induced by sodium nitroprusside in patients with intracranial mass lesions. J Neurosurg 1978;48:329331.

74 Davalos A, Cendra E, Teruel J, Martinez M, Genis D: Deteriorating ischemic stroke: risk factors and prognosis. Neurology 1990;40: 1865-1869. 
75 Carlberg B, Asplund K, Hagg E: The prognostic value of admission blood pressure in patients with acute stroke. Stroke 1993;24:13721375.

76 Toni D, Fiorelli M, Gentile M, et al: Progressing neurological deficit secondary to acute ischemic stroke: a study on predictability, pathogenesis, and prognosis. Arch Neurol 1995;52:670-675.

77 Finocchi C, Gandolfo C, Gasparetto B, Del Sette M, Croce R, Loeb C: Value of early variables as predictors of short-term outcome in patients with acute focal cerebral ischemia. Ital J Neurol Sci 1996;17:341-346.

$\checkmark 78$ Chamorro A, Vila N, Ascaso C, Elices E, Schonewille W, Blanc R: Blood pressure and functional recovery in acute ischemic stroke. Stroke 1998;29:1850-1853.

79 Ahmed N, Wahlgren G: High initial blood pressure after acute stroke is associated with poor functional outcome. J Intern Med 2001; 249:467-473.

$>80$ Bhalla A, Wolfe CD, Rudd AG: The effect of 24 $\mathrm{h}$ blood pressure levels on early neurological recovery after stroke. J Intern Med 2001;250: 121-130.

-81 Boreas AM, Lodder J, Kessels F, de Leeuw PW, Troost J: Prognostic value of blood pressure in acute stroke. J Hum Hypertens 2002;16:111116.
82 Aslanyan S, Fazekas F, Weir CJ, Horner S, Lees KR: GAIN International Steering Committee and Investigators. Effect of blood pressure during the acute period of ischemic stroke on stroke outcome: a tertiary analysis of the GAIN International Trial. Stroke 2003;34: 2420-2425.

83 Semplicini A, Maresca A, Boscolo G, et al: Hypertension in acute ischemic stroke: a compensatory mechanism or an additional damaging factor? Arch Intern Med 2003;163: 211-216.

84 Vlcek M, Schillinger M, Lang W, Lalouschek W, Bur A, Hirschl MM: Association between course of blood pressure within the first $24 \mathrm{~h}$ and functional recovery after acute ischemic stroke. Ann Emerg Med. 2003;42:619-626.

$>85$ Rodriguez-Garcia JL, Botia E, de La Sierra A, Villanueva MA, Gonzalez-Spinola J: Significance of elevated blood pressure and its management on the short-term outcome of patients with acute ischemic stroke. Am J Hypertens 2005;18:379-384.

86 Stead LG, Gilmore RM, Decker WW, Weaver AL, Brown RD Jr: Initial emergency department blood pressure as predictor of survival after acute ischemic stroke. Neurology 2005; 65:1179-1183.

87 Dunne JW, Chakera T, Kermode S: Cerebellar haemorrhage - diagnosis and treatment: a study of 75 consecutive cases. Q J Med 1987; 64:739-754.
88 Broderick JP, Brott TG, Duldner JE, Tomsick T, Huster G: Volume of intracerebral hemorrhage: a powerful and easy-to-use predictor of 30-day mortality. Stroke 1993;24:987-993.

89 Dandapani BK, Suzuki S, Kelley RE, ReyesIglesias Y, Duncan RC: Relation between blood pressure and outcome in intracerebral hemorrhage. Stroke 1995;26:21-24.

$>90$ Qureshi AI, Safdar K, Weil J, et al: Predictors of early deterioration and mortality in black Americans with spontaneous intracerebral hemorrhage. Stroke 1995;26:1764-1767.

91 Fogelholm R, Avikainen S, Murros K: Prognostic value and determinants of first-day mean arterial pressure in spontaneous supratentorial intracerebral hemorrhage. Stroke 1997;28:1396-1400.

$>92$ Terayama Y, Tanahashi N, Fukuuchi Y, Gotoh F: Prognostic value of admission blood pressure in patients with intracerebral hemorrhage. Keio Cooperative Stroke Study. Stroke 1997;28:1185-1188.

93 Leira R, Davalos A, Silva Y, et al: Stroke Project, Cerebrovascular Diseases Group of the Spanish Neurological Society. Early neurologic deterioration in intracerebral hemorrhage: predictors and associated factors. Neurology 2004;63:461-467.

\section{Counterstatement}

\section{Editorial: 'Pathophysiology of Brain Ischemia: Penumbra, Gene Expression, and Future Therapeutic Options' (Eur Neur 2005;54:179-180)}

The publication of the above-mentioned editorial was accompanied by an 'Erratum' of which the undersigned author of the editorial had not been informed. He had not been given the opportunity to comment on its content prior to its publication and therefore, a previous clarification of the issue was impossible.

Please note that Prof. Mathias Bähr has personally substantially reviewed the final manuscript of the editorial that explicitly states his co-authorship. Prof. Mathias Bähr knew about and agreed upon the publication of the manuscript.

Dr. Bernhard Schaller 